\title{
The Possibilities of Improving Communication Skills in the Training of Engineering Students
}

\author{
https://doi.org/10.3991/ijep.v10i5.13727 \\ Ildikó Holik ${ }^{(凶)}$, István Dániel Sanda \\ Óbuda University, Budapest, Hungary \\ holik.ildiko@tmpk.uni-obuda.hu
}

\begin{abstract}
New graduates have to meet several expectations on the labour market. Besides their professional knowledge, important skills include good communication, problem-solving, creativity, independence, organisation, leadership, decisive action, dynamism, stress tolerance, analysis, precision, openness, flexibility, co-operation, motivation, digital competence, etc. This paper provides methodological recommendations on preparing young people for the expectations of the labour market. The results of our empirical study draw attention to the importance and possibilities of developing communication skills in higher education.
\end{abstract}

Keywords - Engineering students, communication skills, methodological recommendations.

\section{Introduction}

In present-day higher education, it has become increasingly important for students to gain modern and applicable knowledge during their training, which will help them stand their ground on the labour market [1-5].

This challenge is especially great for engineering students, as graduates also have to adapt to rapid technological development [6-11]. The changing labour market has resulted in a paradigm shift in higher education [12]. What is emphasised more and more are competence development based on labour market demands and practice-oriented, student-centred methods. In engineer training, the demand has appeared that besides scientific knowledge, it should also provide practical and applicable knowledge that will help young people navigate in their everyday life and the world of work. Developing the social skills of engineering students is especially important. Students' integration into the group, maintaining social relationships, co-operation, effective communication, assertiveness and the ability to solve problems are all indispensible for their successful studies and their future work.

At the same time, however, the question arises how higher education can prepare young people for the challenges of our age. How can adult people's skills be developed in tertiary education?

Several studies have dealt with the qualities required by job advertisements [1-3,13]. Besides the relevant qualifications, foreign language knowledge and computer literacy, 
good communication and negotiation skills, problem solving ability, organisational and managerial skills, decisive action, high load capacity, the ability to work independently, good analytical skills, creative thinking, precise work, flexibility, team spirit, high motivation and success orientation are regarded as basic requirements [13]. It is often expected in the world of work that the employee be able to solve problems and elaborate new projects in co-operation with colleagues working in different places in the world and having different cultural backgrounds. All this can only be based on digital literacy [14] as well as good written and oral communication and co-operation skills $[11,15]$.

Labour market expectations include both hard and soft skills.

The knowledge which can be learnt in the school, from books, is generally referred to as hard skills. It is relatively easy to measure and test and has a tried and trusted evaluation system. Once the students have acquired this general and professional knowledge, it will determine the rules and routines of what and how to do in different situations. Employers can easily be informed about these skills, such as language knowledge, numeracy and the knowledge of computer programmes [11].

Whereas hard skills are relatively easy to recognise and identify, soft skills are much more subjective and harder to define [16].

'Soft skills' is an umbrella term for all the abilities and skills which, in addition to professional competence, will fundamentally determine how the employee can adapt, to what extent (s)he can be motivated and how (s)he can solve different problems [17].

Soft skills include, for example, communication and co-operation skills, taking responsibility, organisational and leadership skills, creativity, problem solving, critical thinking, emotional intelligence, self-control, self-knowledge and self-efficacy [15, 1822].

These skills and abilities are often interrelated. For example, effective communication cannot exist without knowing and accepting ourselves. Our social skills, co-operation, empathy and tolerance determine how sensitive we are to the signals from our environment, how we respond to the communication of others and how we communicate with others. Our creativity can help solve communication problems.

In Positive Education, the latter skills are improved during the learning process, as part of the educational environment [18].

It is important to state that hard and soft skills are equally important and their synergy in higher education can provide more efficient learning and teaching processes and an improvement in the quality of education [15]. The development of hard skills is markedly present in the training programmes of Hungarian higher education institutions, whereas the deliberate improvement of soft skills is much less so.

\section{The Methodology}

Previous studies have shown that assertiveness and good communication skills are indispensable on the labour market $[1,3,23]$.

In the labour market, employees are expected to have proper speaking skills, that is, the ability to understand spoken language and to express themselves appropriately. In the case of written communication, the key skills are clarity, understandability and 
reading comprehension. On the list of skills expected of fresh graduates, co-operation, effective communication and motivation often precede professional knowledge and foreign language skills.

These skills are also expected of engineers, as globalisation has resulted in an everincreasing demand for flexible, adaptive and communicative engineers [9]. Employers expect new graduates not only to have professional knowledge but also to be able to deal with people and be good team-workers [24].

Engineers have to co-operate and communicate with other engineers, their subordinates doing operative work, marketing and financial experts, traders and several other company employees participating in the division of labour, as well as the representatives of other companies, foreign partners and, for example, during the presentation of products, even with users/clients [1].

At the same time, however, several studies highlight the shortcomings of engineers. Schomburg [25] draws attention primarily to the lack of social, communicative and personal competences. Lappalainen [8] and Direito [26] also mention engineers' weaknesses (e.g. effective communication, co-operation, team-work, project management and life-long learning; that is, the lack thereof).

Our own study has also proven the importance of communication and the necessity to improve the communication skills of engineering students [11].

The aim of our research was to map the competences of informatics engineering students and to consider the development possibilities.

The following questions were posed in our study:

- How important students consider communication on the labour market

- How they evaluate their own communication skills

- How active, talkative, friendly and open they are.

Our study was conducted in the academic years of 2016/2017 and 2017/2018 and altogether 475 freshmen informatics engineering students were surveyed $(90.9 \%$ of them male and $9.1 \%$ female).

The average age was 20.15 . The youngest student was 18 years old and the oldest one was 35 . The majority $(33.7 \%)$ of the participants was 19 years old.

Most of the students live in the capital (37.3\%), $11.8 \%$ in a county seat, $33.18 \%$ in some smaller town and $17.9 \%$ of them lives in a village.

Their majority, $30.3 \%$, took the final exam in a traditional secondary school of 4 years and $28.8 \%$ in a vocational school.

Most of the participants (77.3\%) have work experience: $27.6 \%$ of them had student jobs in their secondary school years, $70.1 \%$ summer jobs, $32.2 \%$ worked after secondary school and $9.7 \%$ of them are working students [27].

\section{$3 \quad$ Results and Discussion}

We started examining the competences of informatics engineering students with a 24-item competence list that we had compiled on the basis of job advertisements and other higher education competence surveys. On one hand, we surveyed how necessary 
students thought each competence was necessary for their future profession and on the other hand, to what extent they were in possession of the given competence [27-29].

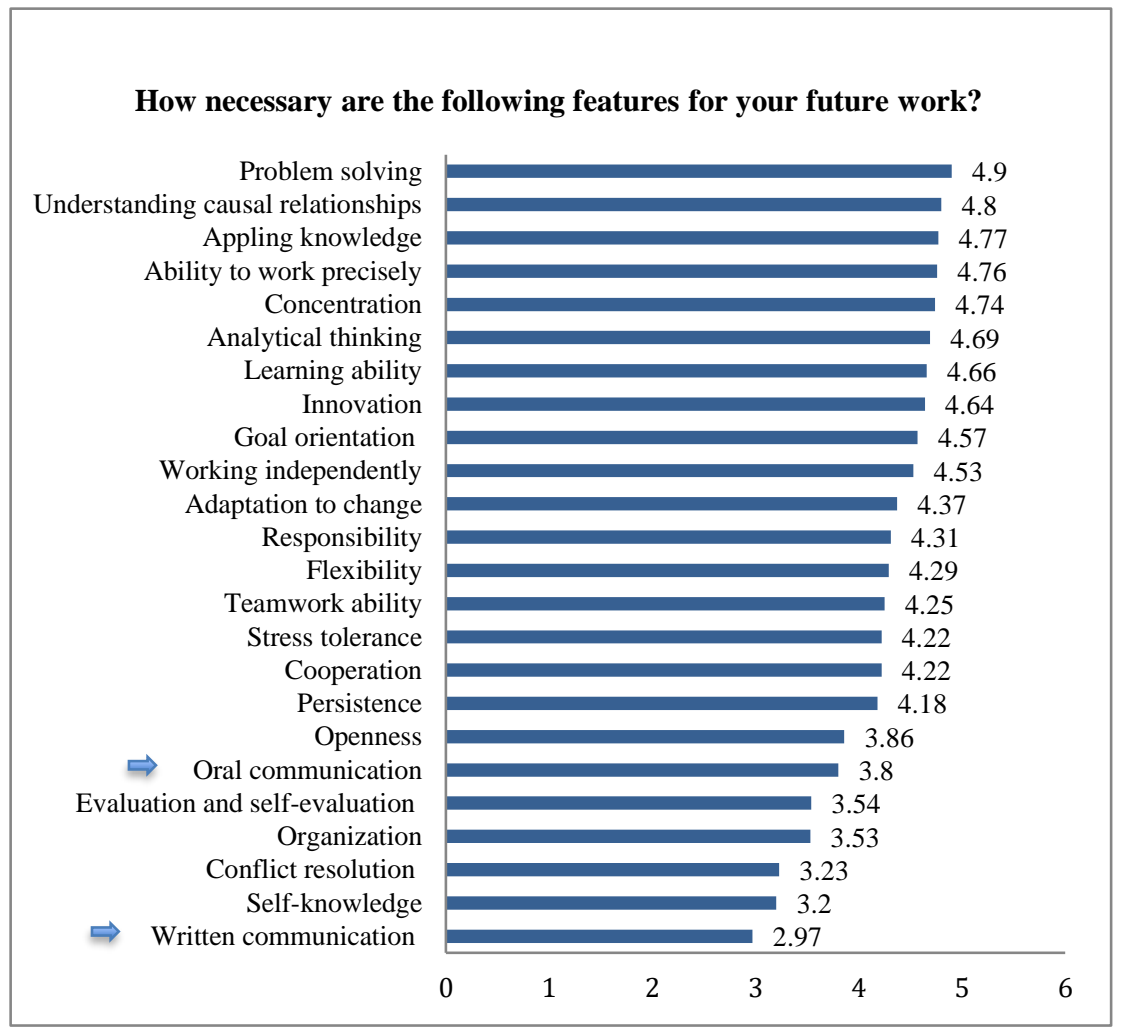

Fig. 1. The evaluation of the competences regarded as important on the labour market (average scores, rated on a 5-point scale, $\mathrm{N}=475$ )

Participants were asked to rate the importance of each competency in future employment using a 5-point Likert scale rating from (1) of minimum importance to (5) of maximum importance, and to self-evaluate their level of proficiency in the same competences at the present moment rating from (1) at a minimum level to (5) at a maximum level $[11,28,29]$. We used the list of competences to find out how important students think communication is on the labour market (see Figure 1).

The two sets of competences show acceptable internal consistency (Cronbach's alpha: 0.816 and 0.872 ).

The results were highly educational. Interpersonal and communication skills ranked $19^{\text {th }}$, whereas writing and composition skills ranked $24^{\text {th }}$, that is, last on the list of skills necessary on the labour market [11].

Clearly, the surveyed students regard several other competences as more important. 
As far as their own existing characteristics were concerned, interpersonal and communication skills ranked $23^{\text {rd }}$ and writing and composition skills ranked $22^{\text {nd }}$ according to students' self-evaluation (see Figure 2).

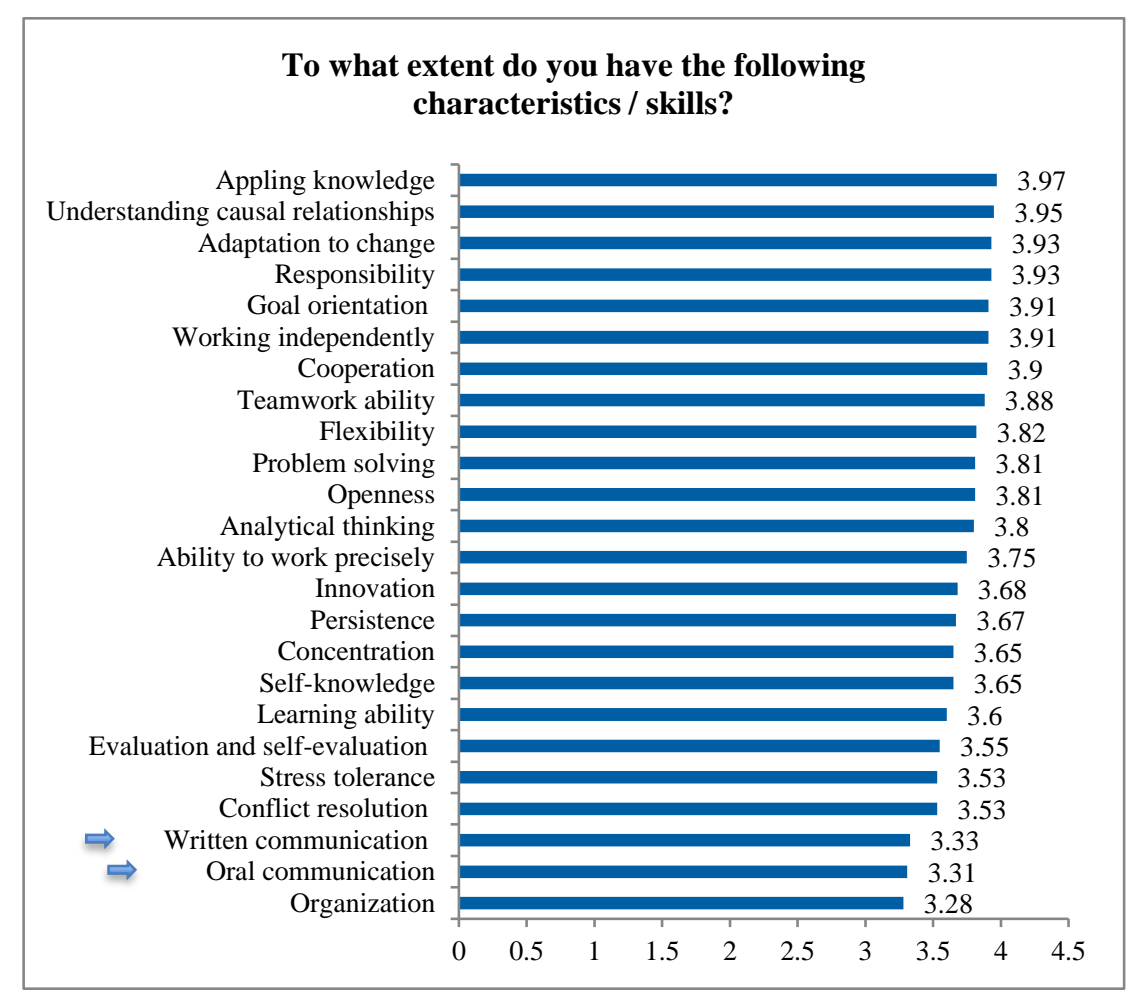

Fig. 2. The evaluation of subjects' own competences (average scores, rated on a 5-point scale, $\mathrm{N}=475$ )

Communication scored remarkably low, which indicates that the surveyed students find this area difficult to navigate. From the received data, we concluded that engineering students need improvement in both oral and written communication.

When studying the relationship with background variables, on the basis of the Chisquared test done on the data, we found significant correlation in the area of written communication. Writing and composition skills are more characteristic of women, according to their own evaluation $(41.9 \%$ of them to a great extent, $18.6 \%$ to a very great extent, whereas only $28.2 \%$ of men have them to a great extent and $13.8 \%$ to a very great extent; $\mathrm{p}=0.034$ ).

For the further study of students' personality, the Big Five Questionnaire was used $[30,31]$. This personality questionnaire includes 5 dimensions and 10 sub-scales, as well as a social desirability scale, which shows to what extent respondents wish to present themselves in a positive light (see Table 1). 
Students evaluated 132 items on a 5-point self-evaluation scale, (1) meaning 'does not apply at all' and (5) meaning 'does apply entirely'.

(Ladnai [32-33] also draws attention to the role of relationships and the importance of their improvement.)

Table 1. Factors and sub-scales of the BFQ, based on [30]

\begin{tabular}{|c|c|c|}
\hline Factors & Sub-scales & Characteristics \\
\hline \multirow[t]{2}{*}{$\begin{array}{l}\text { Energy } \\
\text { lively, extroverted, captivating }\end{array}$} & Dynamism & $\begin{array}{l}\text { dynamic, active, communicative, en- } \\
\text { thusiastic }\end{array}$ \\
\hline & Dominance & dominant, self-confident \\
\hline \multirow[t]{2}{*}{$\begin{array}{l}\text { Friendliness } \\
\text { helpful, understanding, tolerant }\end{array}$} & Cooperativeness & $\begin{array}{l}\text { cooperative, sensitive to the needs of } \\
\text { others, empathic }\end{array}$ \\
\hline & Politeness & $\begin{array}{l}\text { polite, kind, humane, well-meaning, } \\
\text { obedient }\end{array}$ \\
\hline \multirow[t]{2}{*}{$\begin{array}{l}\text { Conscientiousness } \\
\text { responsible, tidy, diligent }\end{array}$} & Scrupulousness & $\begin{array}{l}\text { accurate, precise, reliable, regular, } \\
\text { thorough }\end{array}$ \\
\hline & Perseverance & $\begin{array}{l}\text { persistent, steady, able to carry through } \\
\text { activities }\end{array}$ \\
\hline \multirow[t]{2}{*}{$\begin{array}{l}\text { Emotional stability } \\
\text { balanced, calm, patient }\end{array}$} & Emotion control & $\begin{array}{l}\text { able to control their emotions and cope } \\
\text { with anxiety }\end{array}$ \\
\hline & Impulse control & $\begin{array}{l}\text { able to control their impulsivity (man- } \\
\text { aging anger and irritability) }\end{array}$ \\
\hline \multirow{2}{*}{$\begin{array}{l}\text { Openness } \\
\text { creative, imaginative, well-informed }\end{array}$} & Openness to culture & open to cultural things, cultural interest \\
\hline & Openness to experience & $\begin{array}{l}\text { open to novelty and to values, customs } \\
\text { and ideas different from their own }\end{array}$ \\
\hline
\end{tabular}

As regards the reliability of the questionnaire, the value of Cronbach alpha was 0.860 , which is considered good.

Table 2. Means and standard deviations (SD) of Engineering Informatics students in five personality factors and social desirability scale compared with the Hungarian norm group (raw scores, $\mathrm{N}=475$ )

\begin{tabular}{|l|c|c|}
\hline & $\begin{array}{c}\text { Engineering informative students Mean } \\
\text { SD }\end{array}$ & $\begin{array}{c}\text { Hungarian norm group (N =774) Mean } \\
\text { (SD) }\end{array}$ \\
\hline Energy & $74.87(12.06)$ & $77.51(11.85)$ \\
\hline Friendliness & $78.40(10.09)$ & $82.25(10.09)$ \\
\hline Conscientiousness & $81.89(10.80)$ & $81.34(11.11)$ \\
\hline Emotional stability & $73.03(12.59)$ & $68.60(15.83)$ \\
\hline Openness & $79.55(11.11)$ & $85.52(6.88)$ \\
\hline Social desirability & $34.17(5.45)$ & $29.54(6.88)$ \\
\hline
\end{tabular}

In comparing our own survey results with those obtained during the Hungarian adaptation of the BFQ [31], in the dimensions of Energy, Friendliness and Openness, our students scored lower, in the dimension of Conscientiousness, near average and in the dimension of Emotional stability, they scored higher. On the Social desirability scale, our surveyed students scored higher, which indicates that they want to be seen in a more favourable light (positive distortion) (see Table 2). 
Converting the raw scores to a standardised T-value, we grouped the averages obtained in different colleges into low - average - high categories. $(\mathrm{T}<45$ : low, $45<=\mathrm{T}<=55$ : average, $\mathrm{T}>55$ : high) (see Table 3).

Table 3. Distribution of the sample in the low, average and high zones of BFQ dimensions $(\mathrm{N}=475)$

\begin{tabular}{|l|c|c|c|}
\hline \multicolumn{1}{|c|}{ BFQ Factors } & Low & Average & High \\
\hline Energy & $37 \%$ & $41 \%$ & $22 \%$ \\
\hline Friendliness & $34 \%$ & $43 \%$ & $23 \%$ \\
\hline Conscientiousness & $23 \%$ & $44 \%$ & $33 \%$ \\
\hline Emotional stability & $20 \%$ & $44 \%$ & $36 \%$ \\
\hline Openness & $54 \%$ & $33 \%$ & $13 \%$ \\
\hline Social desirability & $2 \%$ & $35 \%$ & $63 \%$ \\
\hline
\end{tabular}

On the basis of occurrence frequency in the low, average and high zones, we can see that in the Energy factor, the majority of surveyed students are only active and communicative to an average or lesser extent, which suggests weaker social skills. Results indicate that the majority of respondents are rather reserved and prefer to work independently [27].

As regards the Friendliness factor, they also scored average or below, which suggests that they are characterised by tolerance and unselfishness to a lesser degree. Due to this, they are presumed to be less suitable for team-work and co-operation. However, it would be very important for engineering informatics experts to be able to work in a team. This is also supported by studies and employers also voice this expectation $[1,15]$.

In the area of conscientiousness, most students fall into average or high categories, which means that they are responsible, reliable and precise in their work, which are particularly advantageous traits in the field of engineering.

In the area of Emotional stability, the majority of respondents reached an average or high score, which indicates that they tend to be balanced, patient and self-controlled.

In the Openness dimension, the vast majority scored low, which indicates adherence to traditions and routine procedures, the avoidance of change and innovation, less original and creative thinking and a low-level knowledge and openness to culture. This may pose a problem because information technology is the fastest developing branch of industry, where innovation, creativity, seeking novelties and rising to new challenges are everyday requirements for professionals working in this field.

The analysis of the data has shown that respondents are only active, communicative, friendly, tolerant and unselfish to average or lesser extent and they are characterized by only a low degree of openness.

Therefore, they need improvement in the areas of openness, communication and cooperation [27].

We also studied whether there was any correlation between communication as a perceived competence and the dimensions (low, average and high zones) of the BFQ (see Table 4). 
Table 4. Correlations between BFQ dimensions and perceived competences $(\mathrm{N}=475)$

\begin{tabular}{|l|l|c|}
\hline \multicolumn{1}{|c|}{ BFQ dimension } & \multicolumn{1}{c|}{ Which competences they have } & Sign. \\
\hline Energy & Interpersonal and communication skills & 0,000 \\
& writing and composition skills & 0,000 \\
\hline Friendliness & Interpersonal and communication skills & 0,025 \\
\hline Conscientiousness & Interpersonal and communication skills & 0,042 \\
\hline Emotional Stability & Interpersonal and communication skills & 0,003 \\
& writing and composition skills & 0,000 \\
\hline Openness & & \\
\hline
\end{tabular}

In the dimensions of Friendliness, Conscientiousness, Emotional Stability and Openness, there were significant differences between students belonging to the low, medium and high zones, in the self-evaluation of the following competences (Table 4).

This means that students falling into the low zones of the BFQ scored significantly lower in the case of communicative competence than students belonging to the medium or high zones.

\section{$4 \quad$ Improvement Actions}

The results of our study are in harmony with our experiences gained during the university training: some students are less energetic or enthusiastic; communicate in a rather reserved way; are reluctant to answer if asked or called on during class and are hard to activate. Even though they may be very well-prepared and may know the answer to every question, the teacher has to coax them into speaking in front of others, which they find difficult. It may be the case that they managed to avoid oral tests or reciting poetry during their school years and did not gain any experience in "performing" in front of others/strangers and they did not learn how to express themselves fluently. Often, their lack of communicative competences presents a further hindrance to their academic achievement, especially in the case of subjects where oral performance is also evaluated.

Therefore, we consider it important to improve students' communicative skills at university courses.

What is the role of university training here? It would be a solution to provide students with as many opportunities as possible to speak and interact, to elaborate their opinions and standpoints, to share their experiences, professional and personal alike and to make them interested in actively participating in their own learning processes.

We provide several optional subjects for engineering students which may aid the development of their communication skills.

Our Communication course focuses on students' verbal and non-verbal communication.

The course discusses the basic concepts of communication as well as its theoretical and practical questions. Within the topic of verbal communication, it deals with the

\footnotetext{
${ }^{1}$ Based on the Chi-squared test
} 
characteristics of the lecture, explanation and discussion as forms of communication and the techniques for asking questions. It also includes the topics of debate, argumentation and the dispute as a practical example. The characteristics of non-verbal communication are also highlighted. Further topics include the factors determining the effectiveness of communication, convincing and influencing. We study the characteristics of communication in different arenas: at school, at work and at home. Hot issues today are visual communication and illustration; and the effect technical development is having on communication is also an interesting topic.

To study the different theoretical issues of communication, students and all those interested have access to our textbooks in both printed and electronic formats [34-36].

During the practical classes, students complete several communication tasks which improve their verbal expression, vocabulary and presentation techniques. Introductory communication tasks serve the purpose of getting to know each other. Team building tasks help with co-operation and conflict management within the group. The communication skills development tasks help students with their communication at the university and in their everyday lives.

The topics of communication in the family, school and the workplace are of exceptional interest. Students find the topics of communication in the job search process and negotiation techniques extremely important. They also study and practise the issues of assertive communication with great interest.

The course entitled Social Skills Development deals with the past and present of social interactions [37]. Models of human nature and social interactions are highlighted. Another important aspect of the course is how to define ourselves, self-identity, selfimage, self-knowledge, identity and self-attributions. The course also touches upon the topic of objective self-awareness. It also includes the components of human emotions and the interpretation of one's own and others' behaviour.

The concept of extrovertedness and introvertedness, person perception, the accuracy of person perception judgements, and the accuracy of the perception of personality traits are also highlighted.

Further topics include: how our mood affects our person perception judgements; stereotyping; hidden personality theories; person perception and person-types; person-prototypes.

It is a current question how to make a good impression on our environment; what halo effects, priority and novelty effects and stereotyping mean.

The course also deals with finding the causes of behaviour, cause attribution, responsibility attribution and self-serving distortions.

The issue of personal relationship is always received by great interest. It includes attachment and attraction; the theories of attraction; the development of personal relationships; self-esteem and attraction; reciprocity and attraction; similarity of attitudes and attraction.

Social influence is also a current issue, which includes self-disclosure; the varieties of conformity; leadership and leadership styles.

As students will soon have to work together in a group with their co-workers, it is important for them to learn about belonging to a group and interactions within groups, the phases of group development, group infection, conflicts and co-operation among 
groups, group decisions and "group thinking". The issue of role conflict may also draw interest in this age group. Polarizing effects in groups, roles, compliance, prejudices, common stereotypes and the prejudiced personality are all important topics to discuss during the course.

Practical classes held in small groups develop students' self-knowledge and the social skills which make young people more sensitive and more open in their social relationships. By developing communication, conflict management and co-operation skills, the Social Skills Development course contributes to the individual happiness and social success of engineering students [11].

In our practical classes aiming at communication skills development, different methods are employed. An argument or dispute within the group provides an excellent opportunity for students to express their thoughts, elaborate their own standpoints, argue and listen to the other party.

Situational games are entertaining and educational at the same time, allowing students to try themselves out in different situations.

Co-operative methods are also effective in higher education [38]. Employing such methods provide excellent opportunities for the development of social skills, as they are based on student co-operation. The four basic principles of co-operative learning [39]: constructive interdependence, individual responsibility, equal participation and parallel interaction help with the development of soft skills, such as communication skills. Research results draw attention to the fact that employing co-operative learning techniques and courses targeted at the development of social skills have a positive effect on co-operation at work and on personal relationships [40].

The effect can be shown in cases when university students are prepared for co-operation not exclusively by passing on theoretical knowledge but by tasks requiring cooperative work, problem-situations and experience-based learning $[11,41,42,45]$.

\section{Summary}

Young, freshly graduated employees are faced with several expectations on the labour market. Besides having up-to-date scientific and professional knowledge, they must also have the kind of practical knowledge, abilities and skills that will help them navigate in their everyday life and in the world of work. These include, among others, social skills, co-operation, openness and effective communication.

474 informatics engineering students were surveyed with regard to how important they consider communication on the labour market, how they evaluate their own communication skills and how active, communicative, friendly and open they are.

Our survey has drawn our attention to the fact that young people have serious deficiencies in the field of communication. Respondents are only active, communicative, friendly, tolerant and unselfish to average or lesser extent and they are characterized by only a low degree of openness. They especially need improvement in the areas of openness, communication and co-operation.

We apply our research results in practice, too. We provide several optional courses for engineering students which may aid the development of their communication skills. 
During the practical classes, students complete several communication tasks which improve their verbal expression, vocabulary and presentation techniques. Practical classes develop students' self-knowledge and the social skills which make young people more sensitive and more open in their social relationships. By developing communication, conflict management and co-operation skills, our courses contribute to the individual happiness and social success of engineering students.

\section{$6 \quad$ References}

[1] Bajzát, T. (2010). A mérnökök kommunikatív és interkulturális kompetenciája: elvárások és felkészítés (The Communicative and Intercultural Competence of Engineers: Expectations and Preparation). Pécsi Tudományegyetem, Pécs.

[2] Bodnár, É. Csillik, O. Daruka, M. Sass, J. (2017). Varázsszer-e a tükrözött osztályterem? (Is the Reflected Classroom a Magic Potion?) Budapesti Corvinus Egyetem, Budapest.

[3] Híves, T. (2006). Munkaadói elvárások megjelenése az álláshirdetésekben (The Appearance of Employer Expectations in job Advertisements). In: Berde, É. Czenky, K. Györgyi, Z. Híves, T. Morvay, E. Szerepi, A. (eds.): Graduates on the Labour Market.] Felsőoktatási Kutatóintézet, Budapest, pp73-87.

[4] Molnár, Gy. Nagy, K. Szűts, Z. (2018). Development Opportunities of Digital and Labor Market Competences in Higher Education. In: ICERI2018 Proceedings. 11th annual International Conference of Education, Research and Innovation, Seville, pp10590-10594. https://doi.org/10.21125/iceri.2018.2048

[5] Simonics, I. (2017). Use of ICT equipment by engineer teachers and mentors. In: Auer, M. E (Ed.): IEEE Global Engineering Education Conference. EDUCON, Athens, pp527-535. https://doi.org/10.1109/educon.2017.7942897

[6] Markes, I. (2006). A review of literature on employability skill needs in engineering. European Journal of Engineering Education 31: 637-650. https://doi.org/10.1080/03043790600 $\underline{911704}$

[7] Conlon, E. (2008). The New Engineer: Between Employability and Social Responsibility. European Journal of Engineering Education, 33(2): 151-159. https://doi.org/10.1080/030 $\underline{43790801996371}$

[8] Lappalainen, P. (2009). Communication as part of the engineering skills set. European Journal of Engineering Education 34: 123-129. doi: 10.1080/03043790902752038.

[9] Kolmos, A. (2006). Future Engineering Skills, Knowledge and Identity. In: Christensen et al. (eds): Engineering Science, Skills, and Bildung. Aalborg University, Denmark, pp165186.

[10] Williamson, J.M. Lounsbury, J.W. Hanc, L.D. (2013). Key personality traits of engineers for innovation and technology development. Journal of Engineering and Technology Management, 30(2): 157-168. https://doi.org/10.1016/j.jengtecman.2013.01.003

[11] Holik, I. Sanda, I. D. (2019). Methodological recommendations to improve the communication skills of engineering students. In: Borsos, É. Horák, R. Kovács, C. Námesztovszky, Zs. (eds.): Moblility. Book of Selected Papers of the Hungarian Language Teacher Training Faculty's Scientific Conferences. University of Novi Sad Hungarian Language Teacher Training Faculty, Subotica, pp374-380.

[12] Aleryani, A.Y. AlMunifi, A.A. (2019). A Roadmap to the Development of Key Competencies of Engineering and Technology Graduates. (2019) International Journal of Engineering Pedagogy, 5: 75-88. https://doi.org/10.3991/ijep.v9i5.11094 
[13] Engler, Á. (2004). A szociális kompetencia fejlesztése (Improving Social Competence). Magiszter, 2: 13-31.

[14] Duchon, J. (2016). Tanítás és tanulás elektronikus környezetben (Teaching and Learning in an Electronic Environment). Typotop Kft., Budapest.

[15] Daruka, M. (2017). Miért van szükség az innovációk különböző fajtáira a felsőoktatásban? (Why are different types of innovation are necessary in higher education?) In: Bodnár, É. Csillik, O. Daruka M. Sass, J. (szerk.): Varázsszer-e a tükrözött osztályterem? Budapesti Corvinus Egyetem, Budapest, pp6-13.

[16] Mészáros, A. (2017). Labour market expectations towards higher education. In: Safet, B. Sabahudin J. (szerk.): 10th Research/Expert Conference with International Participation. Neum, University of Zenica Faculty of Mechanical Engineering, pp249-254.

[17] Tóth, P. (2017). A tanulási stílus vizsgálata a müszaki felsőoktatásban: Elméleti háttér (A Study of Learning Styles in Technical Higher Education: Theoretical Background). In: Tóth, P. Simonics, I. Duchon, J. Varga, A. (eds.): Pedagógiai kutatások a Kárpát-medencében: II. Kárpát-medencei Oktatási Konferencia: Tanulmánykötet. Partiumi Keresztény Egyetem, Nagyvárad, pp 315-352.

[18] Ladnai, A. (2019). A "pozitív pedagógia” úttörői Magyarországon (The Pioneers of Positi ve Pedagogy in Hungary. Autonomy and Responsibility). Pécsi Tudományegyetem BTK Neveléstudományi Intézet Pécs, 2018-2019 Vol. IV. 1-4. http://nevtud.btk.pte.hu/sites/nevtud.btk.pte.hu/files/files/_af_09_beliv_01.pdf pp25-48. https://doi.org/10.15170/pontes.2018.01.01.06

[19] Bennett, N. Dunne, E. Carré, C. (1999). Patterns of Core and Generic Skill Provision in Higher Education. Higher Education, 37: 71-93. https://doi.org/10.1023/a:1003451727126

[20] Gallivan, M.J. Truex, D.P. Kvasny, L. (2004). Changing Patterns in IT Skill Sets 19982003: A Content Analysis of Classified Advertising. Database for Advances in Information Systems, 35: 64-86. https://doi.org/10.1145/1017114.1017121

[21] Beard, D. Schwieger, D. Surendran, K. (2007). Incorporating Soft Skills into Accou nting and MIS Curricula. In: Proceedings of the 2007 ACM SIGMIS CPR Conference on 2007 Computer Personnel Doctoral Consortium and Research Conference: The Global Information Technology Workforce. St. Louis, MO: ACM, pp179-185. https://doi.org/10. $\underline{1145 / 1235000.1235040}$

[22] Chamorro-Premuzic, T. Furnham, A. (2006). Self-Assessed Intelligence and Academic Performance. Educational Psychology, 26(6): 769-779. https://doi.org/10.1080/014434105 $\underline{00390921}$

[23] Kiss, P. (2010). Diplomás kompetenciaigény és munkával való elégedettség (Competency demand of graduates and job satisfaction). In: Diplomás pályakövetés IV. Frissdiplomások 2010 (Graduate Follow up Survey IV. New Graduates 2010). Educatio Ltd., Budapest, pp $105-130$.

[24] Tong, L.F. (2003). Identifying essential learning skills in students' Engineering education. Learning for an Unknown Future, Proceedings of the 26th HERDSA Annual Conference, Christchurch, New Zealand, 6-9 July 2003, p388.

[25] Schomburg, H. (2007). The professional success of higher education graduates. European. Journal of Education 42: 35-57. https://doi.org/10.1111/j.1465-3435.2007.00286.x

[26] Direito, I. Pereira, A. Olivera Duarte, A.M. (2012). Engineering Undergraduates' Perceptions of Soft Skills: Relations with Self-Efficacy and Learning Styles. Procedia Social and Behavioral Sciences 55: 843-851. https://doi.org/10.1016/j.sbspro.2012.09.571

[27] Holik, I. (2019). Preparing Engineering Students for the Expectations of the Labour Market. In: Isman, A. Eskicumalia, A. Öztunc, M. (eds.) INTE ITICAM Proceedings Book. Sakarya University, Praha, pp529-538. 
[28] Tordai, Z. Holik, I. (2018a). Student's Characteristics as a Basis for Competency Develop ment in Engineering Informatics Education. International Journal of Engineering Pedagogy, 8(4): 32-42. https://doi.org/10.3991/ijep.v8i4.8133

[29] Tordai, Z. Holik, I. (2018b). The Necessity of Competency Development in Engineering Informatics Education in the Light of Students' Characteristics. In: Auer, M. E. Guralnick, D. Simonics, I. (eds): Teaching and Learning in a Digital World: Proceedings of the 20th International Conference on Interactive Collaborative Learning - Volume 1. Springer International Publishing, Cham, pp224-232. https://doi.org/10.1007/978-3-319-73204-6

[30] Caprara, G.V. Barbaranelli, C. Borgogni, L. Perugini, M. (1993). The "big five question naire:" A new questionnaire to assess the five-factor model. Personality and Individual Differences. 15: 281-288. https://doi.org/10.1016/0191-8869(93)90218-r.

[31] Rózsa, S. Kö, N. Oláh, A. (2006). Rekonstruálható-e a Big Five a hazai mintán? [Is it possible to reconstruct Big Five on a Hungarian sample?], Pszichológia (Psychology) 26: 5776.

[32] Ladnai, A. (2019). A „Pozitív pedagógia” lehetséges útjai (The Possible Ways of Positive Pedagogy). In: Autonómia és felelősség Neveléstudományi Folyóirat Pécsi Tudománye gyetem BTK Neveléstudományi Intézet Pécs, 2018-2019 Vol. IV. 1-4. szám http://nevtud.btk.pte.hu/sites/nevtud.btk.pte.hu/files/files/_af_09_beliv_01.pdf(1t.19.11.01.)p25-49. https://doi.org/10.15170/paaa.2016.06.02.08

[33] Ladnai, A. (2018). A Positive Education (PE) modell néhány tanulsága a szociális munka világában (A Positive Education (PE) Some Conclusions Drawn from the Positive Educa tion (PE) model in the World of Social Work). The Basics of Social Work in Schools. (ed. Boros Julianna) http://szockepzes.hu/wp-content/uploads/2019/04/Iskolaiszoci\%C3\%A1lis-munka_BJ-et_al.pdf (1t.19.11.01.) p47-62. https://doi.org/10.29376/parbeszed/2019/1/9

[34] Holik, I. Sanda, I. D. (2016). Tanári kommunikáció (Teacherly Communication). Typotop Kiadó, Budapest.

[35] Holik, I. Sanda, I. D. (2017). Kommunikáció leendő mérnököknek (Communication for Future Engineers). Óbudai Egyetem, Budapest.

[36] Holik, I. Sanda, I. D. (2018). Kommunikáció az egyetemi foglalkozásokon (Communi cation at University Classes). In: Tóth, P. (ed.) Pedagógiai kézikönyv oktatóknak. Typotop Kft., Budapest, pp28-36.

[37] Sanda, I. D. (2019). Szociális készségfejlesztés leendö mérnököknek (Social Skills Develo pment for Future Engineers). Óbudai Egyetem, Budapest.

[38] Pap-Szigeti, R. (2007). Kooperatív módszerek alkalmazása a felsőoktatásban (Applying Co-operative Methods in Higher Education). Iskolakultúra, 1: 56-66.

[39] Kagan, S. (2015). Kooperatív tanulás (Cooperative learning). Ökonet, Budapest.

[40] Smith, K.A. Sheppard, S.D. Johnson, D.W. Johnson, R.T. (2005). Pedagogies of Engage ment: Classroom-Based Practices. Journal of Engineering Education 94: 87-101. https:// doi.org/10.1002/j.2168-9830.2005.tb00831.x

[41] Kolosai, N. Darvay, S. Bihariné Krekó, I. Zombori, J. Nagyné Horváth E. Gradvolh, E. Soósné Kiss Zs. Lukács, J. Á. Füzi, A. Biró, F. Falus, A. Feith, H. J. (2018). Meg fogod tanulni, ő hogyan értelmez: A kortársoktatás hatékonyságának egyik meghatározó aspektusa (You will learn how they interpret: a defining aspect of the effectiveness of peer education). Tanítani online, (68)9. 15 p. https://doi.org/10.1556/2066.2.2018.13

[42] Szarka-Bögös R. Kolosai N. (2016). Tanítók nevelési értékeinek vizsgálata (A Study of Teachers' Educational Values). In: Vitályos, G. Á. M. Pintér, T. (eds.): Mester és Tanítvány II. 86-108. 
[43] Füzi, B. Jármai, E. (2020). The Features and Types of University Students' from the Viewpoint of Teachers. In: Linda, Daniela (ed.) Proceedings of ATEE Spring conference Innovations, Technologies and Research in Education, 2019. University of Latvia, Riga, pp601620. https://doi.org/10.22364/atee.2019.itre.44.

[44] Tomory, I. (2020). A szociális készségeket fejlesztő módszerek alkalmazása a műszaki tanárképzésben (Applying methods for the development of social skills in technical teacher training). In: Simonics, I. Holik, I. (Eds.): Új kutatások a szakképzés és a felsőoktatás területén: IX.Trefort Ágoston Szakképzés- és felsőoktatás-pedagógiai konferencia tanulmá nykötet. Óbudai Egyetem, Budapest, pp78-89.

[45] Pogatsnik, M. (2018). Dual Education: The Win-Win Model of Collaboration between Universities and Industry. International Journal of Engineering Pedagogy (IJEP) 3: 145152. https://doi.org/10.3991/ijep.v8i3.8111

\section{$7 \quad$ Authors}

Ildikó Holik is an associate professor at the Óbuda University Kálmán Kandó Faculty of Electrical Engineering Ágoston Trefort Centre for Engineering Education, Budapest, Hungary. She graduated from the University of Debrecen as a teacher of Mathematics and Pedagogy in 2000 and from the Eötvös Loránd University as a teacher of Information Technology in 2003; she obtained a degree in Business Informatics at the University of Debrecen in 2011. She obtained a PhD degree in pedagogy at the University of Debrecen in 2007; her dissertation dealt with the role of practice schools for trainee teachers. Her major fields of research include engineering education and teacher training.

István Dániel Sanda is an associate professor at the Óbuda University Kálmán Kandó Faculty of Electrical Engineering Ágoston Trefort Centre for Engineering Education, Budapest, Hungary. He graduated from the University of Szeged as a researcher and teacher of Pedagogy. He obtained a PhD degree in pedagogy at the Eötvös Loránd University in 2009. His dissertation was entitled Examining Educational Spaces with Special Regard to Hungarian Schools in the $20^{\text {th }}$ Century. His major fields of research are the history of education and teacher training.

Article submitted 2020-02-12. Resubmitted 2020-05-19. Final acceptance 2020-05-23. Final version published as submitted by the authors. 